\title{
Malignant conversion of a solitary papilloma in the distal trachea: Report of a case
}

\author{
Achilleas Lioulias MD¹, Panagiotis Misthos MD, Georgios Papagiannakis MD¹, Dimitrios Mermigkis MD²,
} Napoleon Karagianidis $\mathrm{MD}^{2}$, Kostas Neofotistos $\mathrm{MD}^{1}$, John Kokotsakis $\mathrm{MD}^{1}$

\begin{abstract}
A Lioulias, P Misthos, G Papagiannakis, et al. Malignant conversion of a solitary papilloma in the distal trachea: Report of a case. Can Respir J 2008;15(7):375-376.

A solitary papilloma versus the usual multiple lesions of papillomatosis is extremely rare. Even more infrequent is a solitary papilloma of the trachea in an adult patient. In the present report, a case of a solitary papilloma in the distal trachea is presented. After two unsuccessful sessions of laser ablation, resection of the lower one-third of the trachea was performed through a right posterolateral thoracotomy. Postoperative histology results disclosed a malignant degeneration into squamous cell carcinoma. The patient had an excellent outcome after resection of the affected portion of the trachea. There was no evidence of recurrence after 20 months of follow-up.
\end{abstract}

Key Words: Distal trachea; Papilloma; Squamous cell carcinoma; Surgical management

Dapillomatosis presents as multiple lesions, most commonly in the larynx or the subglottic segment of the trachea, and occurs usually in children or adolescents. Solitary papillomas are extremely rare. Even more infrequent is a solitary papilloma of the tracheobronchial tree. The present report describes a case of a solitary papilloma in the distal trachea with malignant degeneration into squamous cell carcinoma in an adult patient.

\section{CASE PRESENTATION}

A 57-year-old man who had dyspnea for the previous six months presented with mild hemoptysis. His physical examination was unremarkable, and he had a history of arterial hypertension. A computed tomography scan of the thorax showed the presence of a tumour in the lower one-third of the trachea.

The patient underwent bronchoscopy, and an intraluminal mass was visualized (Figure 1). Multiple biopsies taken from the mass revealed dysplasia along with papillomatous hyperplasia. Human papillomavirus 11 (HPV-11) infection was serologically documented from the specimen. The patient underwent two sessions of laser ablation of the tumour, along with antiviral treatment in a four-month period because of recurrent papillomas at the same site.

One month after the second session of laser ablation, the tumour recurred along with tracheal stenosis due to the development of fibrous tissue, causing severe dyspnea (Figures 2 and 3). Resection of the lower one-third of the trachea was performed through a right posterolateral thoracotomy. Histology results of the resected trachea showed infiltration

\section{Conversion d'un papillome solitaire de la trachée distale en une tumeur maligne : Rapport de cas}

Le papillome solitaire est extrêmement rare par opposition aux multiples lésions habituelles de la papillomatose. Il est encore plus rare d'observer un papillome solitaire de la trachée chez un patient adulte. Le présent rapport fait état d'un cas de papillome solitaire au niveau de la trachée distale. Après l'échec de deux séances d'ablation au laser, une résection du tiers inférieur de la trachée a été réalisée par thoracotomie postérolatérale droite. Les résultats histologiques post-opératoires ont confirmé la présence d'une dégénérescence maligne en un carcinome épidermoïde. Le patient a très bien évolué après la résection de la portion touchée de la trachée. Après 20 mois de suivi, il n'y avait toujours aucun signe de récidive.

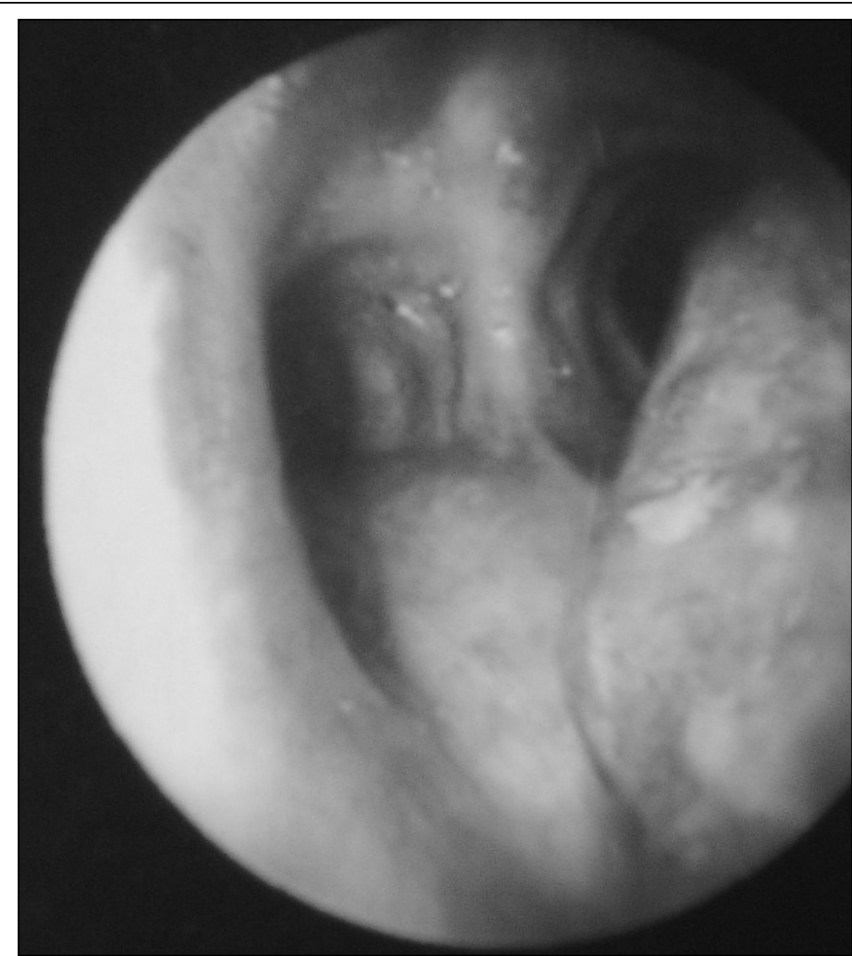

Figure 1) Bronchoscopic view of the tracheal lesion at the time of the patient's initial diagnosis

by squamous carcinoma. The postoperative course was uneventful and the patient was discharged home on the

${ }^{1}$ Thoracic Surgery Department; ${ }^{2} 3 r d$ Pulmonary Department, Sismanogleio General Hospital, Athens, Greece

Correspondence: Dr Panagiotis Misthos, 16-18 Markou Avgeri Street, 15343 Agia Paraskevi, Athens, Greece.

Telephone/fax 00-30-210-608-0107, e-mail panmisthos@yahoo.gr 


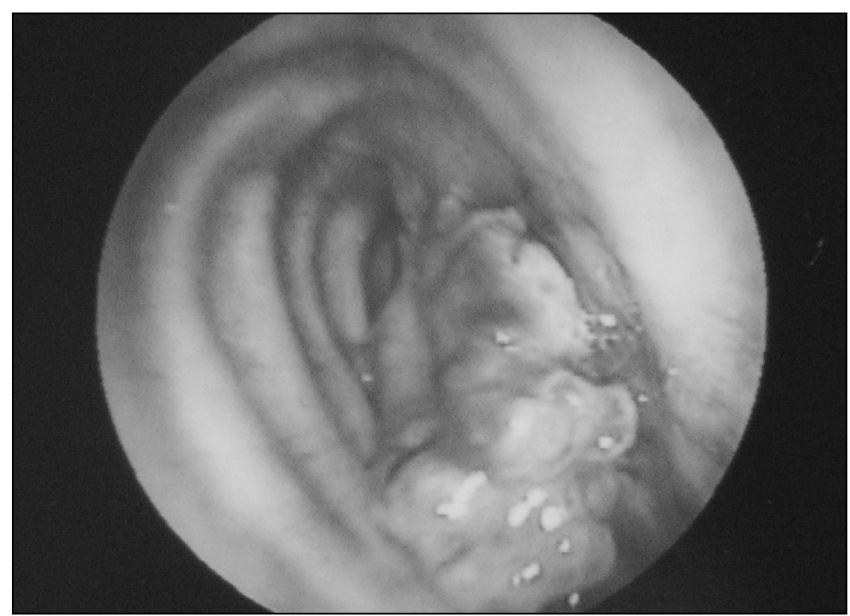

Figure 2) Recurrent tumour at bronchoscopy, after laser sessions

eighth postoperative day. The patient had an excellent longterm outcome, and there was no evidence of recurrence after 20 months of follow-up.

\section{DISCUSSION}

Tracheobronchial papillomas are caused by HPVs, either HPV-6 or HPV-11 (1-3). Its incidence in patients older than 15 years is 1.8 cases per 100,000 people (1). The most common site of development is the subglottic area of the trachea, usually as multiple lesions. The malignant transformation of upper respiratory tract papillomatosis to squamous cell carcinoma is rare and occurs in 3\% to $5 \%$ of patients (1). Malignant transformation may be idiopathic or due to carcinogen exposure $(2,3)$. Our case is extremely rare because of the age of the patient. It is also the second case of a solitary papilloma in the distal trachea with malignant conversion to be reported in the literature (1-8).

Dyspnea on exertion and hoarseness are the most common symptoms. Other, less common, symptoms are chronic cough, hemoptysis, repeated respiratory infection and a sensation of obstruction at the throat $(1,4)$.

Thoracic imaging may show a tracheobronchial lesion, atelectasis (segmental or lobar) or obstructive pneumonia. Computed tomography is the diagnostic method of choice for upper airway lesions, documenting the size, location and involvement of surrounding structures. Pulmonary function tests are indicative of upper intrathoracic airway obstruction with flattening in inspiratory and/or expiratory phases. The typing of the virus by polymerase chain reaction-restriction fragment length polymorphism or other molecular biological methods may have a role in determining a prognosis $(2,3,5,6)$.

Surgical resection is the preferred therapy for primary tracheal tumours such as squamous cell carcinoma and papilloma $(1,4)$. Alternative treatment modalities include repeated laser therapy and photodynamic therapy with photosensitizing agents such as dihematoporphyrin ether, and intralesional and/or systematic antiviral drugs $(1,7)$. In our case, laser ablation was followed by recurrence of papilloma as well as tracheal stenosis due to the development of fibrous tissue.

There was no evidence of viral inclusion particles in the tumour. However, the tumour was found in the papilloma specimen that was previously free of malignancy. Episomal and

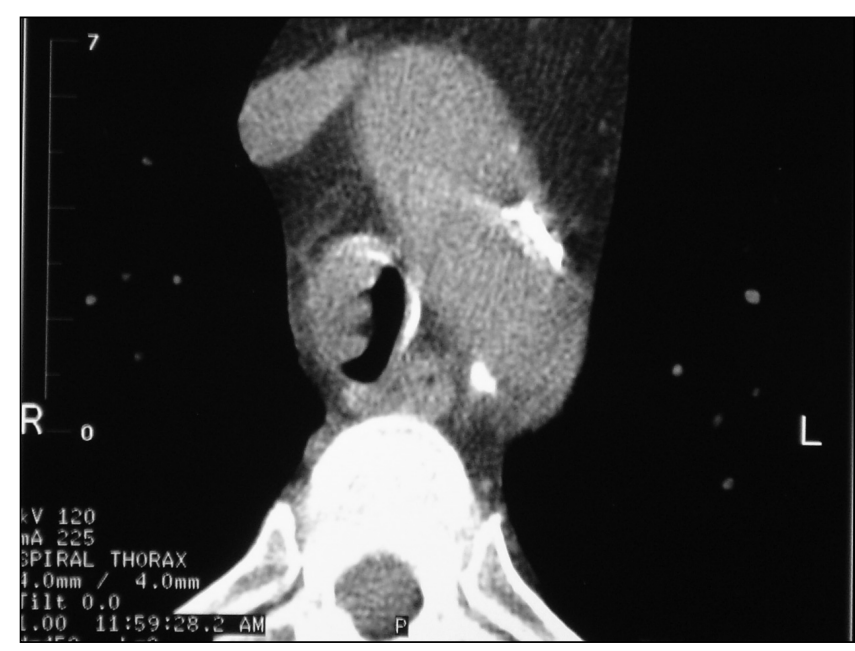

Figure 3) Computed tomography scan of the distal trachea before surgery

integrated forms of HPV-11 sequences were detected in histologically benign tumours, but only the integrated form of the viral DNA was found in malignant tissue samples. Molecular genetic studies (6) have revealed that the p53 genetic mutation is associated with the integration of HPV-11 in histologically malignant lesions. This association may promote a progressive genetic instability that can lead to the development and clonal expansion of malignant lesions in recurrent respiratory papillomatosis (3).

\section{CONCLUSION}

Although recurrent respiratory papillomatosis is generally considered a benign situation, there is a possibility of malignant transformation. The authors recommend frequent follow-up of these lesions. Surgical management offered excellent results in the present case.

\section{REFERENCES}

1. Eloise M. Recurrent respiratory papillomatosis. eMedicine 2003. $<$ http://www.emodicine.com/med/topic2535.htm> (Version current at August 15, 2007).

2. Byrne JC, Tsao MS, Fraser RS, Howley PM. Human papillomavirus-11 DNA in a patient with chronic

laryngotracheobronchial papillomatosis and metastatic squamouscell carcinoma of the lung. N Engl J Med 1987;317:873-8

3. Rady PL, Schnadig VJ, Weiss RL, Hughes TK, Tyring SK. Malignant transformation of recurrent respiratory papillomatosis associated with integrated human papillomavirus type 11 DNA and mutation of p53. Laryngoscope 1998;108:735-40.

4. Wood DE. Management of malignant tracheobronchial obstruction. Surg Clin North Am 2002;82:621-42.

5. Harada H, Miura K, Tsutsui Y, Mineta H, Urano M, Abe M, Kuroda M, Kasahara M. Solitary squamous cell papilloma of the lung in a 40-year-old woman with recurrent laryngeal papillomatosis. Pathol Int 2000;50:431-9.

6. Guillou L, Sahli R, Chaubert P, Monnier P, Cuttat JF, Costa J. Squamous cell carcinoma of the lung in a nonsmoking, nonirradiated patient with juvenile laryngotracheal papillomatosis. Evidence of human papillomavirus-11 DNA in both carcinoma and papillomas. Am J Surg Pathol 1991;15:891-8.

7. Aaron SL, Wong E, Tyrrell D, et al. Interferon treatment of multiple pulmonary malicnancies associated with papilloma virus. Can Resp J 2004;11:443-6.

8. Lam CW, Talbot AR, Yeh KT, Lin SC, Hsieh CE, Fang HY. Human papillomavirus and squamous cell carcinoma in a solitary tracheal papilloma. Ann Thorac Surg 2004;77:2201-2. 


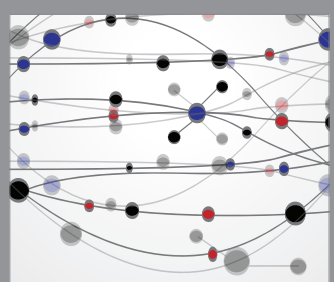

The Scientific World Journal
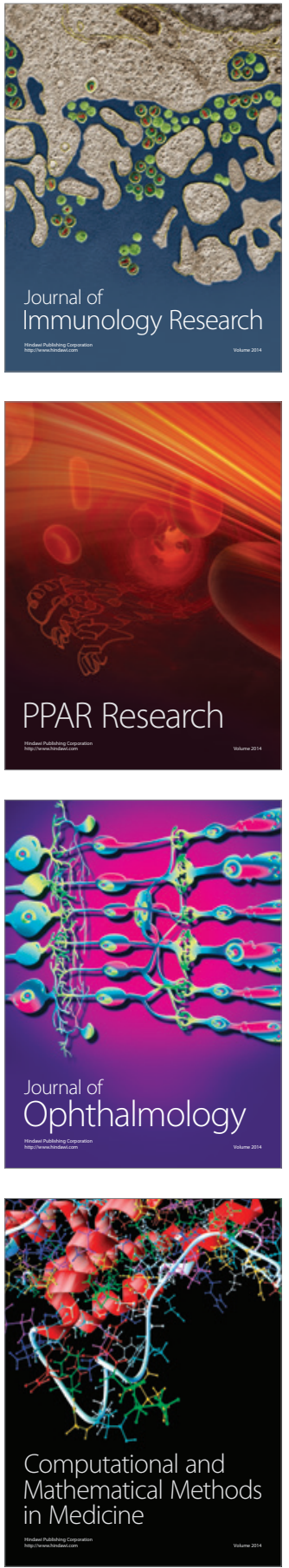

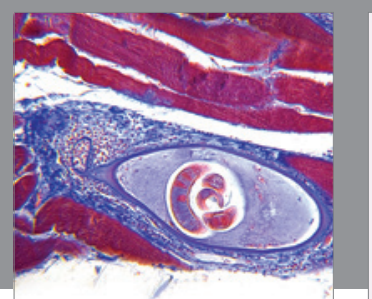

Gastroenterology Research and Practice

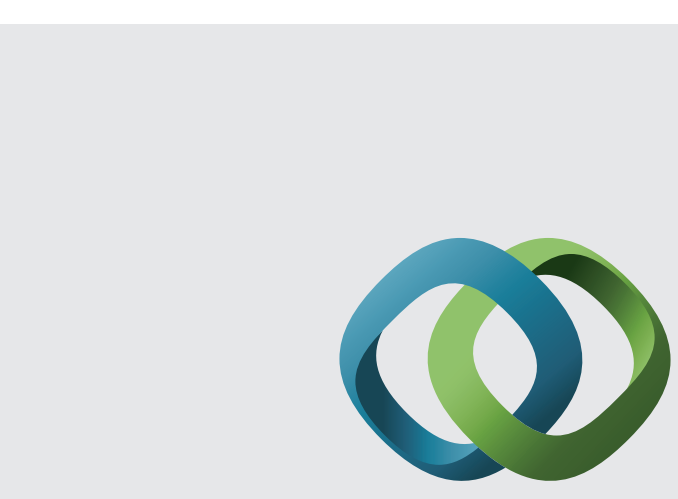

\section{Hindawi}

Submit your manuscripts at

http://www.hindawi.com
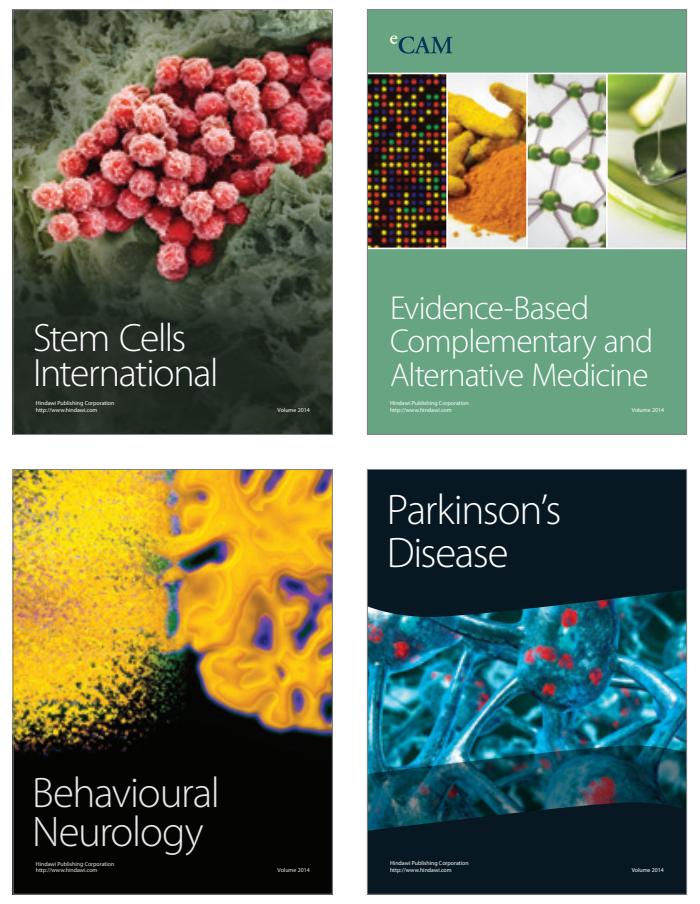
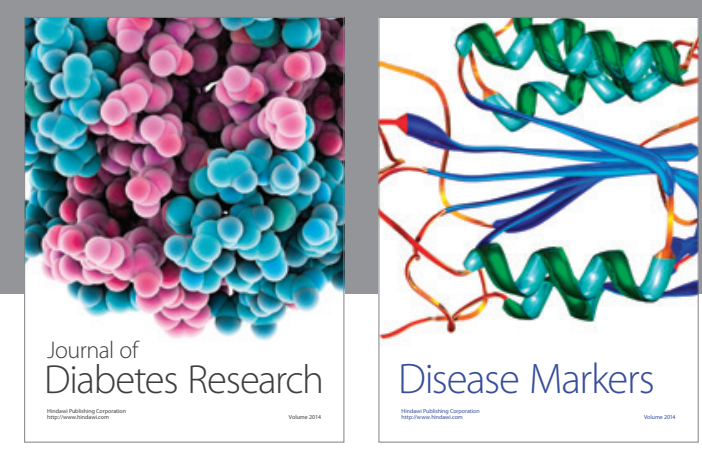

Disease Markers
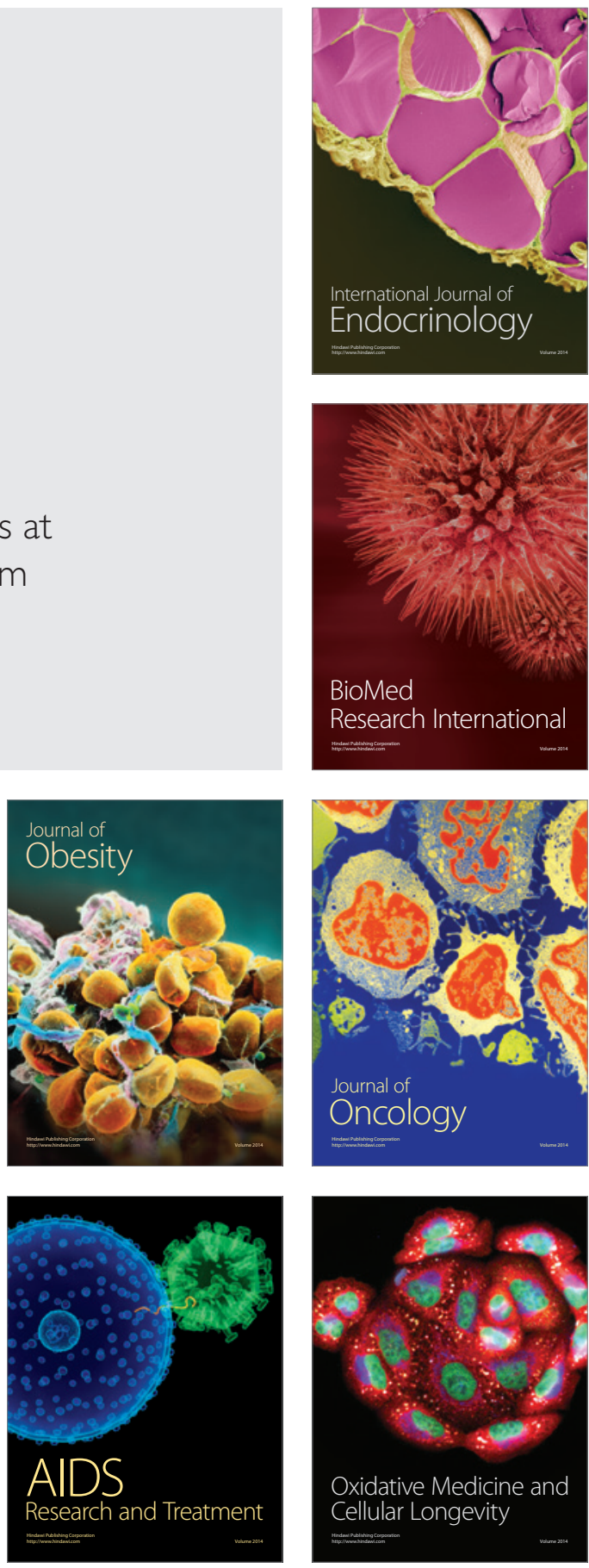